\title{
Learning Society in Accelerating the Increase of English Under- standing and Communicating at Mahesa Putri English Camp
}

\author{
Wiwin Yulianingsih ${ }^{1}$, Gunarti Dwi Lestari ${ }^{1}$, Utari Dewi ${ }^{1}$, Rezka Arina Rahma ${ }^{2}$ \\ ${ }^{1}$ Universitas Negeri Surabaya, Indonesia \\ ${ }^{2}$ Universitas Negeri Malang, Indonesia \\ *Email: wiwinyulianingsih@unesa.ac.id
}

Submitted: 5 October 2020. Revised: 24 November 2020. Accepted: 13 February 2021

\begin{abstract}
Camp is one form of non-formal education that is used as a place to live while undergoing language courses. This study is generally aimed at determining the learning society in accelerating the improvement of understanding skills and communication skills in a camp-based English course for students in Mahesa Putri Camp in English Village. The purpose of this study is to determine the role of camp as an enhancer of understanding ability, and the role of camp as an acceleration of communication patterns. The research method used is descriptive qualitative which describes something objectively, based on data analysis conducted at the time of data collection and after data collection. Data collection techniques used were observation, interviews and documentation. In this study, the subjects of the study were managers, tutors and students at Mahesa Putri Camp English Village Pare, Kediri. From the results of the study, it was found that the students experienced an increase in understanding of learning and motivation from activities in the campThe importance of this research to provide and understanding of the existence of camp provides an acceleration in learning english.
\end{abstract}

Key words: Learning Society, Acceleration, Understanding, Communication Pattern

How to Cite: Yulianingsih, W., Lestari, G. D., Dewi, U., \& Rahma, R. A. (2021). Learning Society in Accelerating the Increase of English Understanding and Communicating at Mahesa Putri English Camp. Journal of Nonformal Education, 7(1), 39-46.

DOI: http://dx.doi.org/10.15294/jne.v7i1.26481

\section{INTRODUCTION}

The development of human abilities, both physically and spiritually, is a matter that takes place in human life for a learning process and improves skills in a relatively short time. Therefore, prioritize the learning needs of the students, through a bottom-up learning concept is not a top-down ( $\mathrm{Su}, 2007)$. This is very attractive to some people, and only exists in courses and training programs. Considering how meaningful this is, the Constitution No. 20/2003, Article 26 stated that courses and training are conducted for people who need knowledge, skills, life skills, and attitudes to develop themselves, develop the profession, work, independent business, and/ or continuing education to a higher level. Therefore, the course is considered as a very productive investment.

According to Ruhamak, Pare is one of the subdistricts in Kediri Regency, East Java that has various types of language courses offered, especially those in Tulungrejo village where various types of language courses have sprung up, but the one that dominates is English courses (Ruhamak \& Rahayu, 2017). This is evidenced by the recording of more than 100 institute courses. The increasing number of institutions offered are also popping up various types of lodging places, ranging from boarding houses to camps. Many of the residents studying outside Java chose the camps on the grounds that there was a program that required them to always communicate in English while they were inside the camp area, especially at the camp that would be the object of this research.

According to Ruhamak, Tran the Executive Director of Academic Affairs of EF Education First revealed the main findings of the EF English Proficiency Index (EPI) this year, that in general, the English proficiency of adults in Asia is relatively stable compared to last year (Ruhamak \& Rahayu, 2017). This year, Indonesia was ranked 51st out of 88 countries in the world, with the score dropping to 51.58 from 52.14 last year. This score places Indonesia in the 13th position out of 21 countries in Asia and is below the average value of English proficiency in the Asian region itself (53.94). Condition of Indonesian students who do not use English in daily activities (Prihatin, 2019). The Indonesian rating has remained low at the skill level since 2017 and is still below the ranks of other ASEAN countries, such as Singapore with (68.63) at the Very High Skill level, the Philippines (61.84) and Malaysia (58.32) at the High Skill level. Even Indonesia, is below Vietnam (53.12) which is at the Intermediate Skill Level.

Along with the rapid development of the economy in Indonesia, it is estimated that in 2030 Indonesia will need 113 million workers who are proficient in English. This clearly shows that language skills are needed for the progress of the State. The results of the study stated that the professionals who were able to speak English well could earn an income 30-50\% higher than those who could not speak English. 
Something similar happened in Bangladesh, workers who have the language skills of Britain have income levels $1 \%$ higher than workers who do not have the language skills of Britain (Elizabeth J, 2014).

The camp is one form of non-formal education that is used as a place to live while undergoing language courses, such as Mahesa Camp, which has provided an accelerated increase in understanding and communication skills for students (Mindarti et al., 2019). Thus, the impact felt by students and society is in the form of increased ability and also understanding and good communication patterns. This is in line with the opinion of (Aziz, 2017) which is proven by the number of students who experience an increase every year, especially during the holiday season. Therefore, the relevance of the type, field and content of the curriculum developed in the camp must be adjusted to the needs of students, which refers to predictions of the possibility of changes that occur.

Camp is the coursework consists of controlled and partly controlled activities exposing students to excellent communication skills which can be used to achieve success in their mastery of the English language. It also provides opportunities for students to develop their natural innate skills in the context of the English language. Students will immerse themselves in an English speaking environment. This course is also designed to be fun and intellectually stimulating. This will encourage cooperative work that leads students to take responsibility for their progress (Ismail \& Tahir, 2011).

Camp is inseparable from the management system by applying various basic principles, namely Problem Based Learning. According to Fajarini Problem Based Learning is a learning approach which gives course participants the opportunity to learn and think about problems that occur in real life (Fajarini et al., 2016). This is also supported by (Suparman, 2015) who stated that Problem Based Learning is a learning model for students to be able to deepen their course capabilities in programs in the camp environment. The management agrees as stated by (Herlinda et al., 2017) who stated that the various set of activities that have been determined to have a relationship of interdependence between one and the other, and carried out by individual students, institutions or parts, who are given the task to carry out these activities.

Then, the camp provides the function of increasing abilities and also understanding and communication patterns. According to Nadhifah this increase can be interpreted as increasing the degree, level, and enhancing the quality of someone (Nadhifah, 2016).
With this, the ability of students will be formed properly. Then, the meaning of understanding according to Mahmudah is a process of thinking that is fundamental to the direction of efforts for learning (Mahmudah, 2016) .

These statements are in line with (Irawan \& Surjono, 2018) who stated that understanding is the ability of a person to grasp the meaning of what has been learned from someone. From the opinion above, it shows that Mahesa Camp has been very directed to students who live in the camp, which provide programs that support capacity building and also understanding and patterns of good language communication, every day.

The management that is really implemented well makes students more confident to speak English in their daily lives, from waking up to going back to sleep. The students in Mahesa Camp, Pare Kediri does not only come from the Mahesa Course Institute, but also from other course institutions who want to hone their English language skills by staying in the camp, which further strengthens the ability of students in English to exchange information about the rules to speak English ranging from grammar, speaking, pronouncation and vocab.

According to Handayani English language skills possessed will facilitate students in accessing and obtaining information related to English (Handayani, 2016). That becomes very important, because in this increasingly modern era, the majority of information uses English. This is also supported by (Wijayatiningsih et al., 2015) who stated that it occurs because English functions as the language of science, technology and trade. Thus, English language skills must also be sharpened everyday, because it will provide many benefits. This is consistent with the opinion of (Al Basya \& Mawardi, 2018) who stated that the ability to speak English is one of the most decisive abilities in obtaining employment. Thus, the purpose of this research is to find out more about accelerating the improvement of understanding skills and communication of camp-based English for the students at Mahesa Putri Camp, English Village, Pare.

\section{METHODS}

This study used the qualitative research method with a qualitative descriptive approach. The characteristics of the descriptive qualitative research methods, namely: (1) describing events that are factual; (2) is carried out by survey; (3) is looking for infor- 
mation factually and is carried out in detail; (4) is to identify problems or to justify the situation and ongoing practices; (5) is describing the subject being managed by a certain group of people at the same time (Raco, 2010).

In this study, the subjects of the study were Managers, Tutors and students at Mahesa Putri Camp English Village Pare, Kediri. The main instrument in collecting data in this study is the researcher himself, or called the human instrument. The researcher is the one who acts as the main data collector whose purpose is to collect data/information.

The steps in analyzing data according to (Sugiyono, 2017) were by reducing data, presenting data, and drawing conclusions. Then to check the validity of the data using the test: (1) credibility or truth value, using source triangulation; (2) transferability or dependability; (3) dependability or audit of the entire research process; (4) confirmability or certainty and can also be called objectivity test.

\section{RESULTS AND DISCUSSION}

\section{Camps to Increase Understanding Ability}

From the findings in the field, in general the people of the English Village in Pare is using English in their daily communication. According to (Putera, 2019) the implementation of English is not only institutionalized in the course, but also in the camp, meaning that the participants are encouraged to take part in a series of activities in the camp where they are required to speak English. In addition, the course apply learning by repetition, singing, debates and games (Hendrawaty \& Angkarini, 2013). If there is a student who does not speak English in the camp, then he will get the punishment that applies at the camp.

Mahesa Camp is one of the many camps in English Village, but what makes it unique from many camps in general is a matter of understanding patterns and communication patterns. Until finally the researcher observed directly and blended into one with the participants of the courses in Mahesa Camp. According to (Agustina, 2019), Mahesa Putri Camp conducts daily activities by requiring English in the camp area, which with learning activities that require English in the camp area is very helpful for students in adding English language skills. The concept that was built is in line with problem-based learning, so that learning is centered on student needs (Cheong, 2008). Starting from the tutor who is trying to play a role in an effort to provide understanding in order to improve the quality of the participants. This is im- portant because understanding is the initial capital of participants in digesting, analyzing, and also mapping out knowledge relevant to the times.

The students' speaking competence became higher after camping. Choosing the right activity provides an opportunity to use and learn real English in a relaxed environment. Tutors play an important role in how language is used in camps to create a suitable environment for improving communication skills and incrasing students' comprehension skills (Rodvinij, 2018).

In the cognitive realm, the ability to understand is higher than knowledge, which is discussed with the opinion of (Yulianingsih et al., 2018) that is "the ability of someone to understand something after something is known and remembered". That is, understanding is knowing about what he sees from various aspects. The cognitive processes of course participants, known as metacognition effect on knowledge, social factors and contextual learning (Robert Delisle, 1997). (Karmiani, 2018) stated that understanding is the ability to think at a level higher than one's memory and memorization.

CTL is socially and psychologically beneficial for students, helps make them relax, creates a comfortable classroom atmosphere, creates a relaxed classroom atmosphere, creates bonds between classmates and teachers, increases student interest, and makes learning more enjoyable. This is suitable for the English activity camp so that students can learn foreign languages more quickly (Aswad, 2017). It can be concluded based on field observations and see objectively that understanding the program at Mahesa Camp is to support the tutor's ability to provide material or material given to participants so that participants can understand and understand the material being taught then can conclude and communicate it.

To increase understanding is when students show their ability to write information that is fully known (Taqiyyah et al., 2017). Zuhro \& Hermawati (2017) argued that students' understanding of communicative skills will support the improvement of their knowledge of English. English as a language of communication, international economic and political language has an important role in the world of glass (Boroujeni et al., 2013). Thus, increasing understanding is a conscious effort to increase participants' knowledge so that they can describe the problem and infer from the learning material. This was very visible in Mahesa Camp's atmosphere where all the participants were very active and progressive. The interview results from one of the participants showed that un- 
derstanding in English was obtained from the camp program. The ability was more than an interpretation that had never been felt by participants before. It is also inseparable from the pattern adopted at Mahesa Camp, because the pattern at the camp is very supportive of increasing participants' understanding. The pattern is as follows:

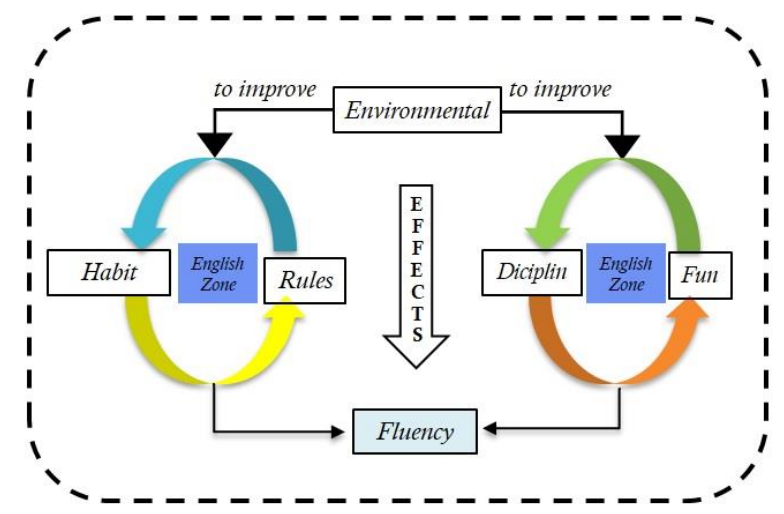

Figure 1. The pattern of rules in Mahesa Camp

\section{Camps in Accelerating Communication Patterns}

The camp is a favorite of every participant involved in learning in English Village, Pare. From the results of the study, the participants who had lived in the camp provided information that there was an increase in learning English, or in other words, was accelerating. Suggested that an acceleration is an increase in the ability of participants to be so quick in accepting and understanding learning (Sunengsih, 2017). This is in agreement with Russel who argued that accelerated learning is a process of accelerating learning that is able to change habits, regarding skills, knowledge, or new attitudes in a person (Russel, 2011). In line with these learners also get accelerated learning through academic conversation between learners with tutors (Zwiers \& Crawford, 2009). Mahesa Camp is able to create an atmosphere that is stress free and is relevant to everything that has been taught to students who stay overnight. According to Karmala the tutors are able to explain the material in outline or the core ideas of the material that has been learned from institutions outside the camp course. From the core material, the tutors convey it with V.A.K or visual, auditory and kinesthetic modalities (Karmala et al., 2018).

Learning through seeing something that is considered interesting by students, namely by visualizing pictures, diagrams, graphs, and clear material maps. Visual communication is needed a medium to explain further the topic that was being discussed (Farkhan \& Lariesa, 2018). We need to be able to communicate visually as well because visuals can enhance written words, and using visuals effectively is a part of good communication. So the participants did not find boredom in the learning process.

Appropriate teaching through listening can provide students with a sound basis for effective and independent learning (Ahmadi, 2016). Teachers can provide material through listening and provide opportunities for students to practice. Learning support through listening is the most effective, followed by visual aids and text as support (Bozorgian \& Pillay, 2013). In Mahesa Camp, the students were learning through listening to material from a tutor, where the tutor is so humble and delivering the material with an encouraging voice intonation is the way of Mahesa Camp to make students always comfortable in the learning atmosphere.

Students are taught how to demonstrate and practice directly to implement the knowledge they have learned. Furthermore, agree with Daniati there is a camp management system in which there is a good communication pattern that will facilitate students in accessing and obtaining information (Daniati, 2016). Furthermore, this pattern help the communicator to remember insights and knowledge, and can be used in combination to create solutions and effective communication (Köppe, 2015).

The students in Mahesa Camp Pare Kediri not only come from the Mahesa Course Institution, but also from other courses with the aim of honing their English language skills, also living in it, so that it further strengthens the ability of students in speaking English and mutual exchange information about English language rules ranging from grammar, speaking, pronouncation and vocab. It related with stated by (Leong et al., 2017) that the students who want to succeed in learning language skills such as listening, speaking, reading and writing must study the language components such as vocabulary, pronunciation and grammar as one of the language components.

The management of the program can be interpreted as an effort to implement management functions both for each activity related to education and for education units and types. As stated by Sujanto regarding management of educational programs for non-formal education and human resource development, John D. Milles, in "Management and Public Service", classifies management functions into two categories, namely: directing and facilitating (Sujanto, 2016). As for management in the management of Mahesa Camp identified sequentially namely plan- 
ning, organizing, mobilizing, coaching, evaluating and developing which can be described as follows:

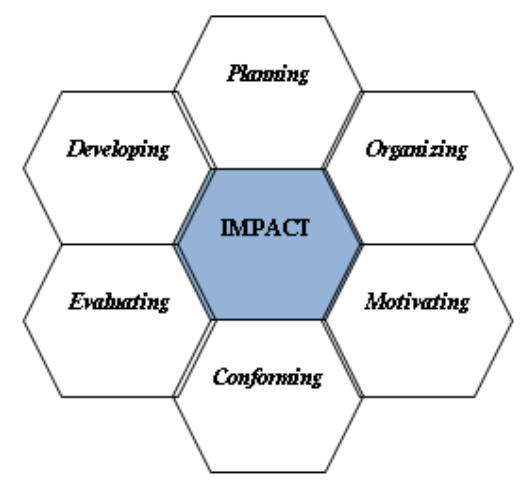

Figure 2. The Management of Mahesa Camp

The Figure 2 serves as a benchmark for a polarization in a basic camp, so that the camp becomes a place that can build and accelerate the learning process of students in English Village. Then the communication polarization in Mahesa Camp focuses on students, one of which uses the communication pattern described as follows:

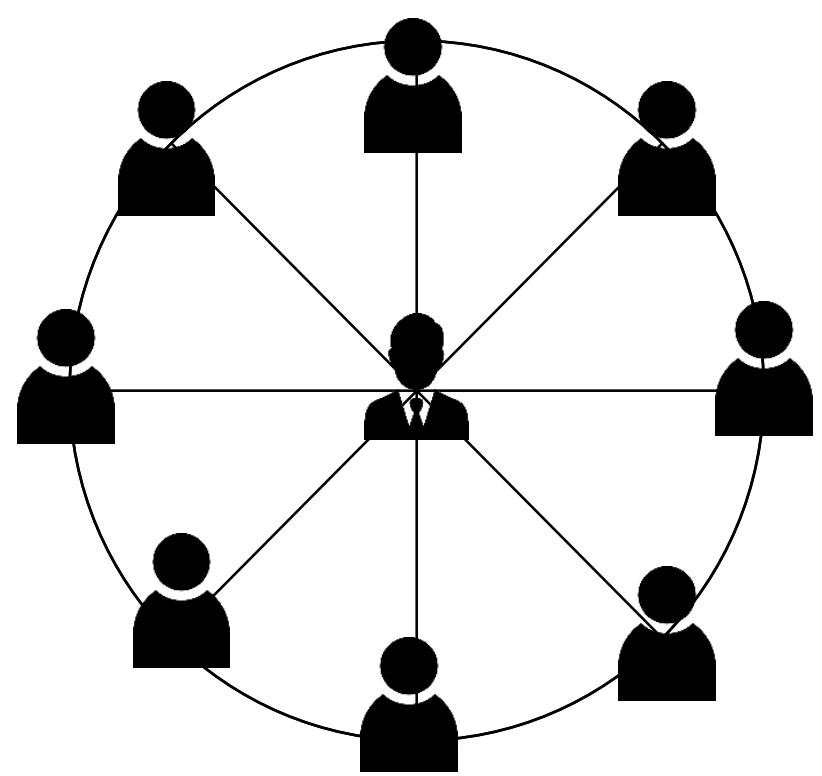

Figure 3. The Communication Polarization in Mahesa Camp

Next, the details of the basic are reviewed again in the camp activities. As an example starting from the basic introduction of The Components of Language in which the review is as follows: (1) phoneme; (2) morpheme; (3) word; (4) phrase; (5) clause; and (6) sentence.
With the communication patterns of the tutors at the camp and by conveying them in a way that is easy to learn, each participant experiences an increase in understanding so quickly. The example explanation is as follows:

\#PHRASE (A meaningful chain of words with a pattern of $\mathrm{S}+\mathrm{P} / \mathrm{S}+\mathrm{V}$

Pattern: $\mathrm{M}+\mathrm{H}+\mathrm{M}$

M: Modifier (explaining) $\rightarrow$ explaining

H: Head (the core) $\rightarrow$ explained

\#CLAUSE (A meaningful chain of words with a pattern of $\mathrm{S}+\mathrm{P} / \mathrm{S}+\mathrm{V}$, It can be a sentence or a part of a sentence.)

- Kinds $\rightarrow$ main clause $(\mathrm{MC}) \rightarrow$ pattern: $\mathrm{S}+\mathrm{V}$ $\rightarrow$ sub clause (SC) $\rightarrow$ pattern : Conj $+\mathrm{S}+\mathrm{V}$

- e.g:

\begin{tabular}{|c|c|c|c|c|}
\hline Heri & Menangis & karena & Tara & pergi \\
\hline $\mathrm{S}$ & $\mathrm{V}$ & Conj & $\mathrm{S}$ & $\mathrm{V}$ \\
\hline Heri & Cries & because & Tara & goes \\
\hline $\mathrm{S}$ & V & Conj & $\mathrm{S}$ & V \\
\hline & $\mathrm{MC}$ & & $\mathrm{SC}$ & \\
\hline
\end{tabular}

Then, in memorizing the Tenses, it uses the means of a marriage of Tenses, the example is as follows:

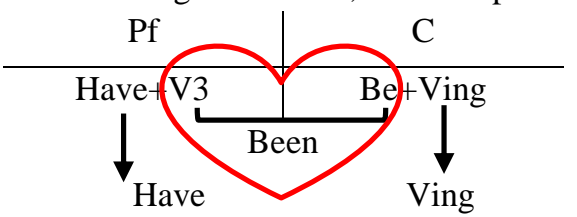

The explanation above shows the formation of well-structured communication patterns, given that communication becomes an important role in human life in interacting in life that is so complex.

Communication skills are essential in science. Camps had a clear and direct impact on the student's communication skills were notably enhanced (SmithPalmer et al., 2015). But in the atmosphere of the camp environment a communication showed that there was feedback on everyone involved. Communication and activities in English villages focus on cooperative learning patterns in which teaching strategies are designed to educate group cooperation and learner participant interactions. In line with what Thrurston each group of learners must have a special role to play in the cooperative learning process. This very important role of communication in the camp (Thurston et al., 2019). 


\section{CONCLUSION}

From the findings of the researchers in the field about the acceleration of increased understanding and communication skills in camp-based English in students at Mahesa Putri English Village Camp it can be concluded that: First, the Camp can improve the ability of understanding that has been going well, and the form of learning should be emulated by the the camps that are currently developing. Then, the camp was able to provide positive stimulus to increase student understanding in English Village. Secondly, the camp is as an acceleration and the communication patterns are very relevant and help students in the learning process while at the course institutions they attend. Therefore this research is very useful and can be used as a reference for future research, certainly more indepth and comprehensive.

\section{REFERENCES}

Agustina, P. dan W. Y. (2019). Hubungan Antara Minat Warga Belajar Dengan Persepsi Diri Tentang Kemampuan Berbahasa Inggris di Camp Mahesa Putri Kampung Inggris Pare Kediri. Jurnal Pendidikan Untuk Semua.

Ahmadi, S. M. (2016). The Importance of Listening Comprehension in Language Learning. International Journal of Research in English Education, 1(1), 4.

Al Basya, Moh. faishal Y., \& Mawardi, M. K. (2018). Analisis Preferensi Konsumen terhadap Keputusan Menggunakan Jasa Kursus Bahasa Inggris (Studi Pada Pelanggan Lembaga Kursus Bahasa Inggris di Kampung Inggris Pare). Jurnal Administrasi Bisnis, 58(2), 197-205.

Aswad, M. (2017). The Effectiness English Camp (A Model in Learning English as the Second Language). 6.

Aziz, F. A. (2017). Kualitas Pelayanan Pendidikan Lembaga Kursus Dan Pelatihan (Lkp) Dian Gitaya. Jurnal Pendidikan Teknik Boga, 1-9.

Boroujeni, S. A., Fard, F. M., \& In, M. A. (2013). A Needs Analysis of English for Specific Purposes (ESP) Course For Adoption Of Communicative Language Teaching:( A Case of Iranian FirstYear Students of Educational Administration). International Journal of Humanities and Social Science Invention ISSN, 2(6), 35-44.

Bozorgian, H., \& Pillay, H. (2013). Enhancing Foreign Language Learning through Listening Strat- egies Delivered in L1: An Experimental Study. International Journal of Instruction, 6(1).

Cheong, F. (2008). Using a Problem-Based Learning Approach to Teach an Intelligent Systems Course. Journal of Information Technology Education: Research, 7, 047-060.

Daniati, E. (2016). Logika Fuzzy Model Tahani untuk Rekomendasi Pilihan Kursus di Kampung Inggris Pare Kediri Fuzzy Logic of Tahani Model for Optional Course Recommendation in English Village Pare Kediri. 3(3), 200-213.

Elizabeth J, E. and T. P. (2014). Synthesis Report: Evidence of the Relationship Between English and Economic Gain in Bangladesh. English in Action, 1-17.

Fajarini, A., Soetjipto, B. E., \& Hanurawan, F. (2016). Developing A Social Studies Module by Using P roblem Based Learning ( PBL ) With Scaffolding for the Seventh Grade Students in A Junior High School in Malang, Indonesia. Journal of Research \& Method in Education, 6(1), 62-69.

Farkhan, M., \& Lariesa, K. (2018). Rusabesi Community's English Language and Communication Patterns. Atlantis Press, 302, 5.

Handayani, S. (2016). Pentingnya Kemampuan Berbahasa Inggris Sebagai Dalam Menyongsong Asean. Ikatan Sarjana Pendidikan Indonesia (ISPI) Jawa Tengah, 3(1), 102-106.

Hendrawaty, N., \& Angkarini, T. (2013). The Acquisition of English As a Foreign Language in Pare East Java (Kampung Inggris). Deiksis, 05, 8.

Herlinda, S., Hidayat, S., \& Djumena, I. (2017). Manajemen Pelatihan Hantaran dalam Meningkatkan Kecakapan Hidup Warga Belajar di Lembaga Kursus dan Pelatihan. Journal of Nonformal Education and Community Empowerment, 1(1), 1-9.

Irawan, R., \& Surjono, H. D. (2018). Pengembangan e-learning berbasis moodle dalam peningkatkan pemahaman lagu pada pembelajaran bahasa inggris. Jurnal Inovasi Teknologi Pendidikan, $5(1), 1-11$.

Ismail, N. S., \& Tahir, I. M. (2011). A Strategy to Enhance Students' English Proficiency. Studies in Literature and Language, 2(3), 12.

Karmala, E. T., Kristina, D., \& Supriyadi, S. (2018). Learning Public Speaking Skills from an Ethnography Study of "Kampung Inggris." English Language and Literature International Conference, 2, 228-230.

Karmiani, S. (2018). Penggunaan Media Komik Berbahasa Inggris Sebagai Upaya Meningkatkan 
Kemampuan Membaca Pemahaman Bahasa Inggris Pada Siswa Kelas Viii Smpn 3 Teluk Kuantan. JURNAL PAJAR (Pendidikan Dan Pengajaran), 2(6), 883.

Köppe, C. (2015). Towards a pattern language for lecture design: An inventory and categorization of existing lecture-relevant patterns. Proceedings of the 18th European Conference on Pattern Languages of Program - EuroPLoP '13, 1-17.

Leong, L.-M., School of Educational Studies, Universiti Sains Malaysia, Malaysia, Ahmadi, S. M., \& University of Guilan, Rasht, Iran. (2017). An Analysis of Factors Influencing Learners' English Speaking Skill. International Journal of Research in English Education, 2(1), 34-41.

Mahmudah, N. (2016). Pemahaman Pengelola Lembaga Kursus Dan Pelatihan ( Lkp ). 5(7), 264273.

Mindarti, L. I., Subroto, R., \& Guritno, S. (2019). The Development of Community-Based Tourism in " Kampung Inggris" Pare, Kediri Regency, East Java Introduction Kampung Inggris is a name of a village located in Pelem Village, Pare District. It is an area where there are many English center institutio. 27(1), 131-148. https://doi.org/10.19105/karsa.v27i1.1776

Nadhifah, G. (2016). Peningkatan kemampuan Pemecahan Masalah Matematis Siswa dalam Menerapkan Model Pembelajaran Problem Based Learning dan Inquiry. Jurnal Mosharafa, 5(1), 33-44.

Prihatin, Y. (2019). The Practice Of English Language Teaching In Indonesia. In PROCEEDING 1st National Seminar of PBI (English Language Education).

Putera, S. A. (2019). Komunikasi Lintas Budaya Dalam Proses Belajar Bahasa Inggris di English Village Pare Kediri. Jurnal Komunikasi, 13(2), 149164.

Raco, J. R. (2010). Metode Penelitian Kualitatif: Jenis, Karakteristik dan Keunggulannya. PT. Gramedia Widiasarana Indonesia.

Robert Delisle. (1997). How to Use Problem-Based Learning in the Classroom. Association for Supervision and Curriculum Development.

Rodvinij, W. (2018). The Implication of Communicative Language Activity in Language Camps. FEU Academic Review Journal, 12(1), 14.

Ruhamak, M. D., \& Rahayu, B. (2017). Pengaruh Word Of Mouth Terhadap Purchase Intention Melalui Brand Image Pada Lembaga Kursus Bahasa Inggris Dynamic English Course Pare.
Ekonika: Jurnal Ekonomi Universitas Kadiri, 1(2), 188-204.

Russel, L. (2011). The Accelerated Learning Fieldbook. Nusa Media Mulyana.

Smith-Palmer, T., Schnepf, S., Sherman, A., Sullenger, K. S., \& Macdonald, L. (2015). An Exploration of Summer Science Camps as an Informal Learning Environment. In K. S. Sahin \& R. S. Turner (Eds.), New Ground (pp. 67-91). SensePublishers.

$\mathrm{Su}, \mathrm{Y}$. H. (2007). The learning society as itself: Lifelong learning, individualization of learning, and beyond education. Studies in Continuing Education, 29(2), 195-206.

Sugiyono. (2017). Metode Penelitian Pendidikan: Pendekatan Kuantitatif, Kualitatif, R\&D. Cetakan Ke-25 (25th ed.). CV. Alfabeta.

Sujanto, A. (2016). Pengembangan Kemitraan Lembaga Kursus Dan Pelatihan (LKP) dengan Dunia Usaha dan Dunia Industri (DUDI) untuk Penjaminan Mutu LKP. Jurnal Infokam, XII(1), 59-65.

Sunengsih, N. (2017). Penningkatan Keterampilan Berbicara Bahasa Inggris Dengan Penerapan Pembelajaran Akselerasi. 59-65.

Suparman, dan H. D. (2015). Peningkatan Kemampuan Berpikir Kreatif Siswa Melalui Penerapan Model Problem Based Learning. Bioedukasi Universitas Khairun, 3(2), 367-372.

Taqiyyah, S. A., Subali, B., \& Handayani, L. (2017). Implementasi bahan ajar sains berbahasa inggris berbasis metakognitif untuk meningkatkan kemampuan pemecahan masalah siswa SMP. Jurnal Inovasi Pendidikan IPA, 3(2), 224.

Thurston, A., Cockerill, M., \& Craig, N. (2019). Using cooperative learning to close the reading attainment gap for students with low literacy levels for Grade 8/Year 9 students. International Journal of Educational Research, 94(November 2018), 1-10.

Wijayatiningsih, T. D., Mulyadi, D., \& Fathurrohman, A. (2015). Drill Dan Repetition Dalam Pelatihan Bahasa Inggris Pemilik Homestay Desa Wisata Kandri Semarang. The 2nd University Research Coloquium.

Yulianingsih, W., Supriyono, Rasyad, A., \& Dayati, U. (2018). The involvement of informal sector workers in society learning activities at kampung inggris pare kediri. Journal of Social Studies Education Research, 9(3), 132-144.

Zuhro, C., \& Hermawati, D. A. (2017). Pelatihan Bahasa Inggris Komunikatif Sebagai Upaya Peningkatan Kualitas SDM Dalam Menghadapi Tan- 
Wiwin Yulianingsih et al. / Journal of Nonformal Education 7 (1) (2021): 39-46

tangan MEA Bagi Santriwati Pondok Pesantren Al-Husna Jember. J-Dinamika, 2(1), 6-10.

Zwiers, J., \& Crawford, M. (2009). Accelerating
Oral Language with Academic Conversations. 810. 